\title{
Reinventing the corporation
}

\author{
Sir John Cass's Foundation Lecture \\ read 3 March 2015 \\ COLIN MAYER \\ Fellow of the Academy
}

\begin{abstract}
The corporation has undergone a fundamental change over the last few decades from an organisation with predominantly tangible assets, such as buildings and equipment, to the 'mindful corporation' with intangible assets, such as brands, patents and reputations. While the corporation has made immense contributions to economic prosperity and development, it is also associated with growing levels of income and social inequality. To correct its deficiencies and restore trust, it needs to be reinvented for the 21 st century. It should be reconceived as a means of commitment to the promotion of the interests of its customers and communities as well as enhancing the wealth of its investors. This requires a careful reconsideration of the purpose of the corporation and its associated forms of ownership and governance. The humanities have a vital role to play in achieving this.
\end{abstract}

Keywords: the corporation, intangible, commitment, trust, purpose, ownership, governance.

\section{PART 1-WHERE WE ARE}

Hesiod had four of them, Ovid five of them and Shakespeare seven of them. 'All the world's a stage and all the men and women merely players. They have their exits and entrances and one man in his time plays many parts his acts being seven ages.' The seven ages of man. 'At first the infant mewling and puking in the nurse's arm. Then the whining schoolboy with satchel and shining morning face, creeping like snail unwillingly to School.' ${ }^{1}$ All very politically incorrect; much safer to stick to the corporation.

There we find six ages. At first the merchant trading company established by royal charter to undertake voyages of discovery and promote commerce around the world. Then the public corporation created by Acts of Parliament to engage in major public

${ }^{1}$ William Shakespeare 'All the World's a Stage', As You Like It, Act II, Scene VII. 
works and the building of canals and railways. Then, with freedom of incorporation in the 19th century, the private corporation emerged - the seedbed of the industrial revolution and the manufacturing corporation. Next came the service firm and the rise of the financial institution. The fifth age was the transnational corporation putting a girdle around the earth and running rings around national governments. Last scene of all that ends this strange eventful history is the mindful corporation - sans machines, sans man, sans money, sans everything.

Figure 1 shows the proportion of the market value of US corporations attributable to tangible assets - plant, machinery and buildings - as against intangibleslicences, patents and research developments. It records that intangibles today account for 80 per cent of the market value of US corporations whereas just 40 years ago tangibles accounted for 80 per cent of stock market values.

Figure 2 shows that the millennium was a turning point when for the first time investment in intangibles exceeded that in tangibles in the UK. We might once have been a nation of shopkeepers, buildings and office blocks - lots of office blocks - but no more. The turn of the millennium marked the turn of Britain into a nation of brands and brains.

A particularly striking feature of this graph is the area in blue - the financial crisis - when tangible investment took a nosedive but not intangibles. Our brands and brains were more resilient than our buildings and office blocks and they have marched on since then.

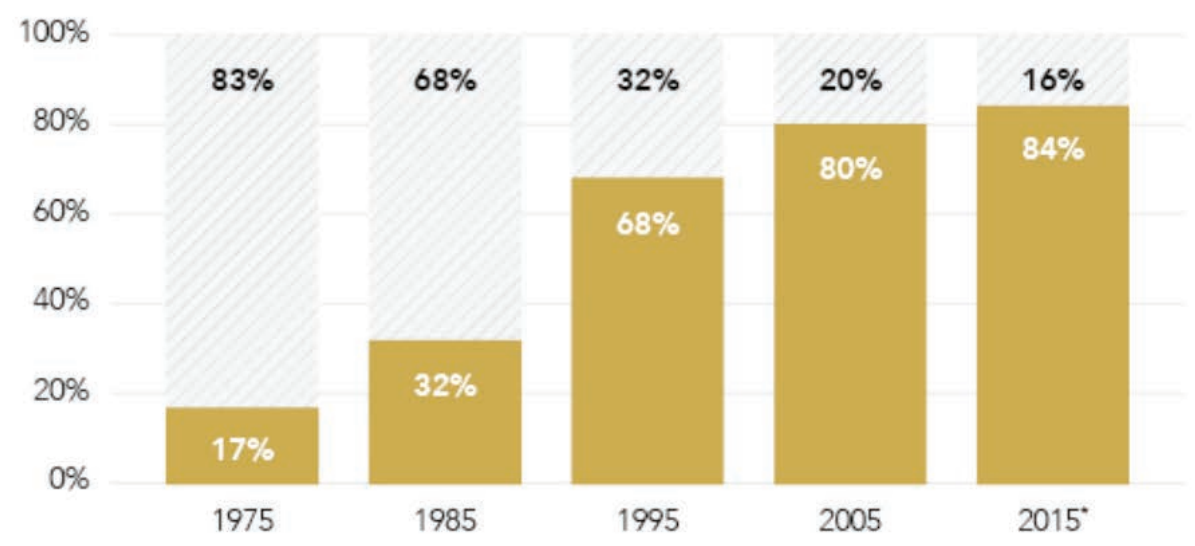

Tangible Assets Intangible Assets

Figure 1. The proportion of the market value of US corporations attributable to tangible assets as against intangibles. (Source: Ocean Tomo LLC.) 


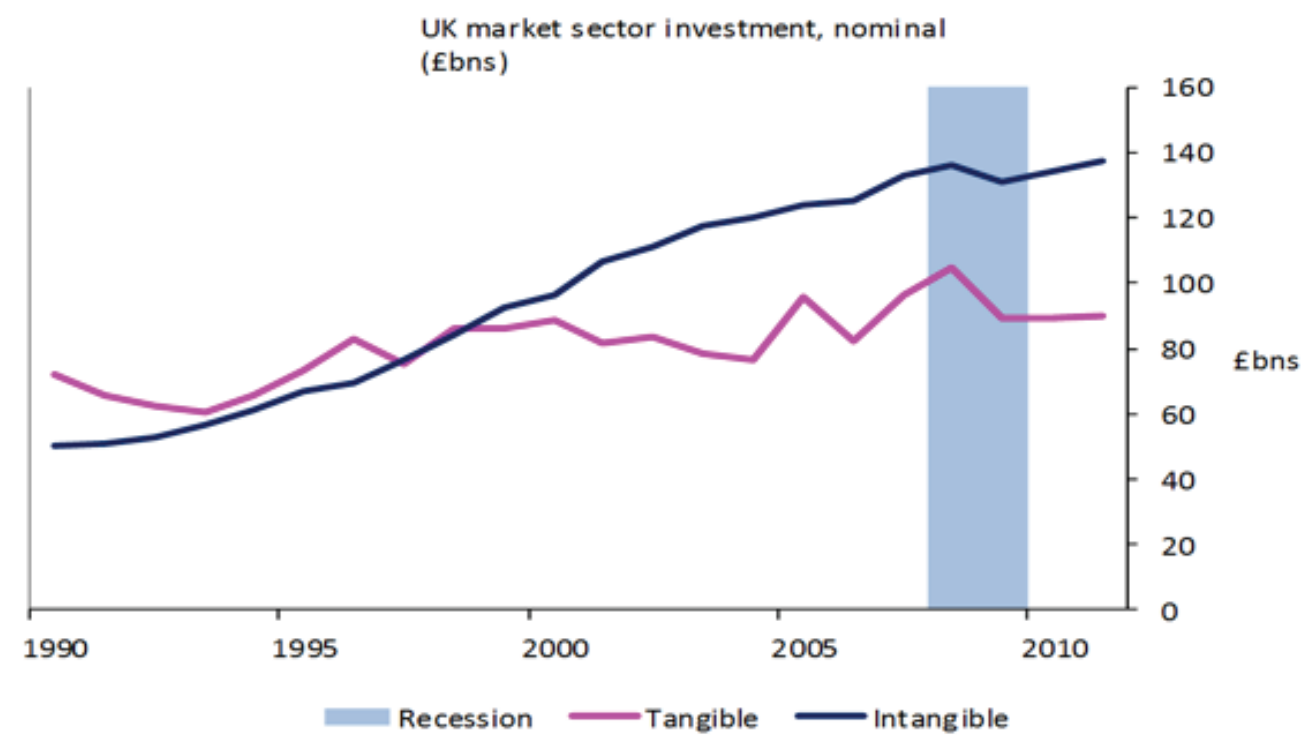

Figure 2. Comparison of investment in intangibles and tangibles over time in the UK. (Source: Goodridge et al. 2014.)

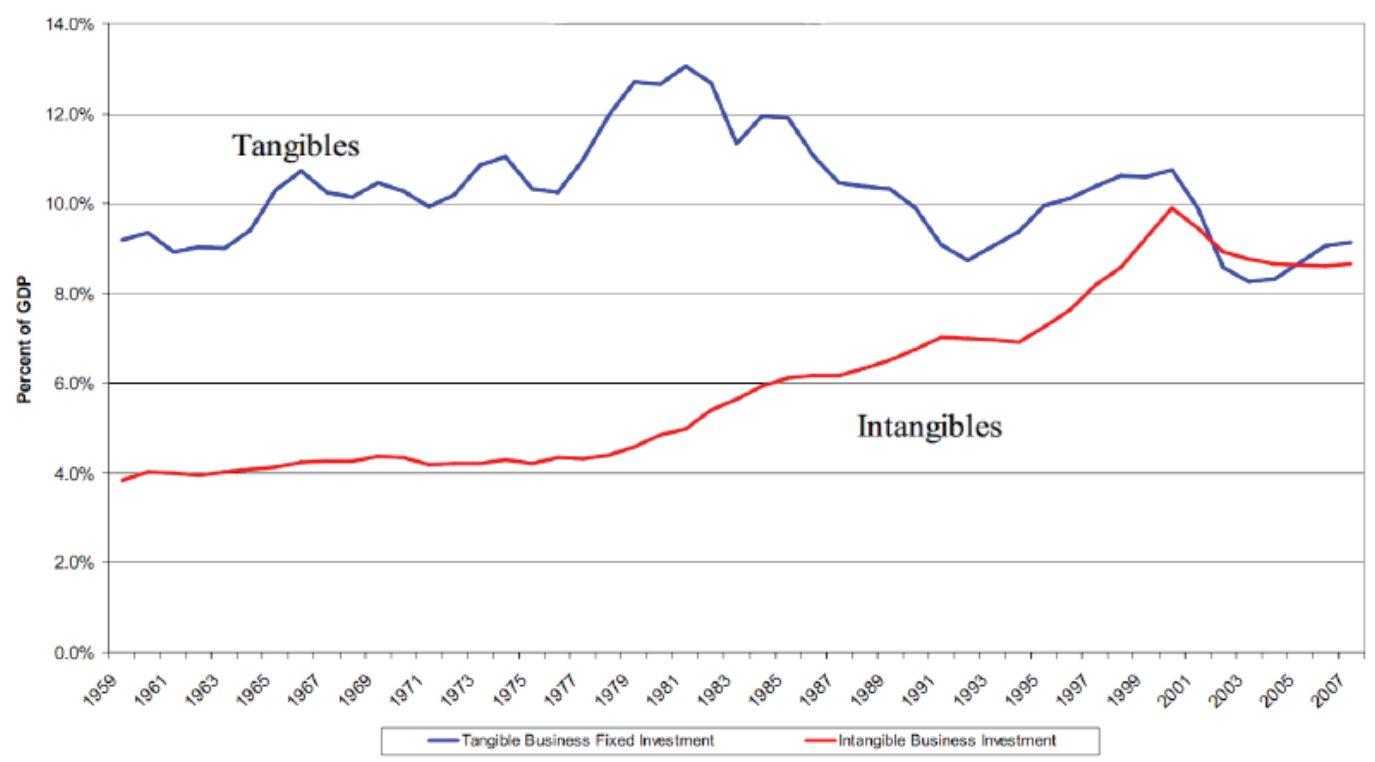

Figure 3. Comparison of investment in intangibles and tangibles over time in the US. (Reproduced with permission from: Nakamura 2009.) 
As you might expect, what Britain does, the US does better (Figure 3). There too the turn of the century marked the turn of the US from manufacturing to minds and while intangibles account for around 6 per cent of GDP in the UK, they are around 9 per cent of GDP in the US.

Reliance on intangibles might feel like placing one's faith in magic; an economy of magicians not manufacturers making nothing but air - the weightless economy. But it is no such thing. The sixth age of the corporation marks the most remarkable period of our existence. It is indeed a corporation sans machines, sans man, sans money, sans everything.

Take Facebook and its founder Mark Zuckerberg as examples. In 2008, Mark Zuckerberg made a very costly decision when he failed to employ two people who had recently left Yahoo!. Instead the two went to the Red Rock Café in Mountain View, California to write computer code on laptops perched on wobbly tables. It was the code for sending messages on cellphones in a cheaper and more reliable form than either SMS or MMS. In October 2009, they raised \$250,000 from five ex-Yahoo! friends.

The two people were Brian Acton and Jan Koum and the company they formed was called WhatsApp, which last year they sold to Facebook for \$19 billion. Instead of employing Acton and Koum for a few thousand dollars back in 2008, Mark Zuckerberg ended up buying their corporate form for $\$ 19$ billion.

This story is made all the more remarkable by the fact that this was a company with not just no machines, no men and no money-it was burning money. In the six months prior to the purchase, WhatsApp made a loss of \$230 million. What was Mark Zuckerberg thinking when he purchased a loss-making company with no assets, no people and lots of liabilities for \$19 billion? Was Mark a magician or mad?

The mindful corporation is an extraordinarily efficient concept. The creation of a corporation worth $\$ 19$ billion on the back of an idea that involves few people, a handful of computers, little space and next to no capital stands in marked contrast to the previous ages of the corporation with their fleets of sailing ships, hoards of labourers, belching factories, teams of service providers, and gleaming transnational headquarters of far-flung corporate empires. They have given way to the mindful corporation.

At the same time as it is an elegant culmination of a process that has been in progress for 600 years, the mindful corporation also embodies the problems that have steadily been emerging. On 19 August 2004, Google came to the NASDAQ stock market at a share price of $\$ 85$ per share in an initial public offering that valued the company at more than $\$ 23$ billion. Today the founders Sergey Brin and Larry Page are each valued by Forbes at $\$ 29$ billion.

But Google not only exemplifies the extraordinary concentration of wealth that the mindful corporation is creating, which by comparison puts the tens of millions of 
dollars of annual income earned by investment bankers into the poverty category, it also illustrates another form of concentration: concentration of power. When Google came to the stock market, it issued two classes of shares - one class that was made available to the public at large and another class that was just held by the founders. The latter had 10 times the voting control of the former. As a result, today Sergey Brin and Larry Page have complete control of Google with a majority of the votes.

This ownership structure was deemed by many analysts and investors at the time to be a violation of good corporate governance and a threat to the ordinary investor. Today in November 2015 the share price is $\$ 750$, an increase of nearly nine-fold from flotation - not bad for a period during which the S\&P index has only approximately doubled. In this case at least, concentration of power does not appear to have acted to the detriment of its investors. Other social media companies, such as Facebook and LinkedIn, and Internet companies, such as Alibaba, also came to the stock market with dual-class share structures that allowed their founders and partners to retain control.

But whether the concentration of ownership and power acts to the detriment of society more generally is a moot issue. Concentration of wealth may be fully justified by the enormous contributions that the founders have made to our lifestyles and well-being; and retention of voting control may be required, as the founders claim, to preserve their corporations' clarity of vision and purpose. But have no illusions- the mindful corporation is creating extraordinary disparities of wealth and power in the hands of those with the minds to create them that make the landed gentry of the past look like impoverished downtrodden farmers.

This is the latest in a long progression of changes to the role of the corporation in contemporary society during its six ages of existence. At the outset it was a public agent - an instrument of the king and then Parliament to promote the national interest in building an empire and then the infrastructure on which we rely to this day.

With freedom of incorporation in 1844, the stranglehold of the state was relaxed and families controlled its development. However, it remained firmly rooted in and dependent on the nation state. Even when it grew into major manufacturing industry and families ceded control, it was dependent on the state for its prosperity. But with the emergence of, first, the multinational and, then, the transnational corporation, which is not only international but stateless, the corporation has become footloose.

Not only has it become footloose, it is also timeless. Kings and parliaments provided a permanence and durability to the purpose of the firm. This was then adopted by families that passed corporations through several generations of ownerssuch as the Barclays and the Cadburys. As families relinquished control to outside investors, ownership was initially retained by individual investors, the euphemistic widows and orphans, for extended periods of time but then transferred to institutions 
that have held them for progressively shorter periods of time as portfolios of assets to be traded at will, a phenomenon that has been observed around the world (Figure 4).

So from entities with persistent ownership beholden to their nation states, corporations have transitioned into organisations with investors with no commitment to any particular nation or generation other than the present. The result is that the interests of the corporation have progressively diverged from those of the societies within which they operate.

Much of what we observe in terms of both flourishing and failures of societies around the world is attributable to the way in which the corporation has evolved. The remarkable growth of China, India, Japan, Korea and Singapore in the post-WW2 period has come on the back of the emergence of corporations owned by the state in China, by banks and other corporations in Japan, and families in India, Korea and Singapore. The failure of Africa and the Middle East to demonstrate similar flourishing reflects an absence of indigenous corporate sectors and over-reliance on foreign subsidiaries. The problems that have recently emerged in Asian economies of environmental pollution in China, of growing levels of income inequality in India, of monopoly distortions in Korea, and of conflicts in bank-firm relations in Japan are attributable to failures of their corporate sectors.

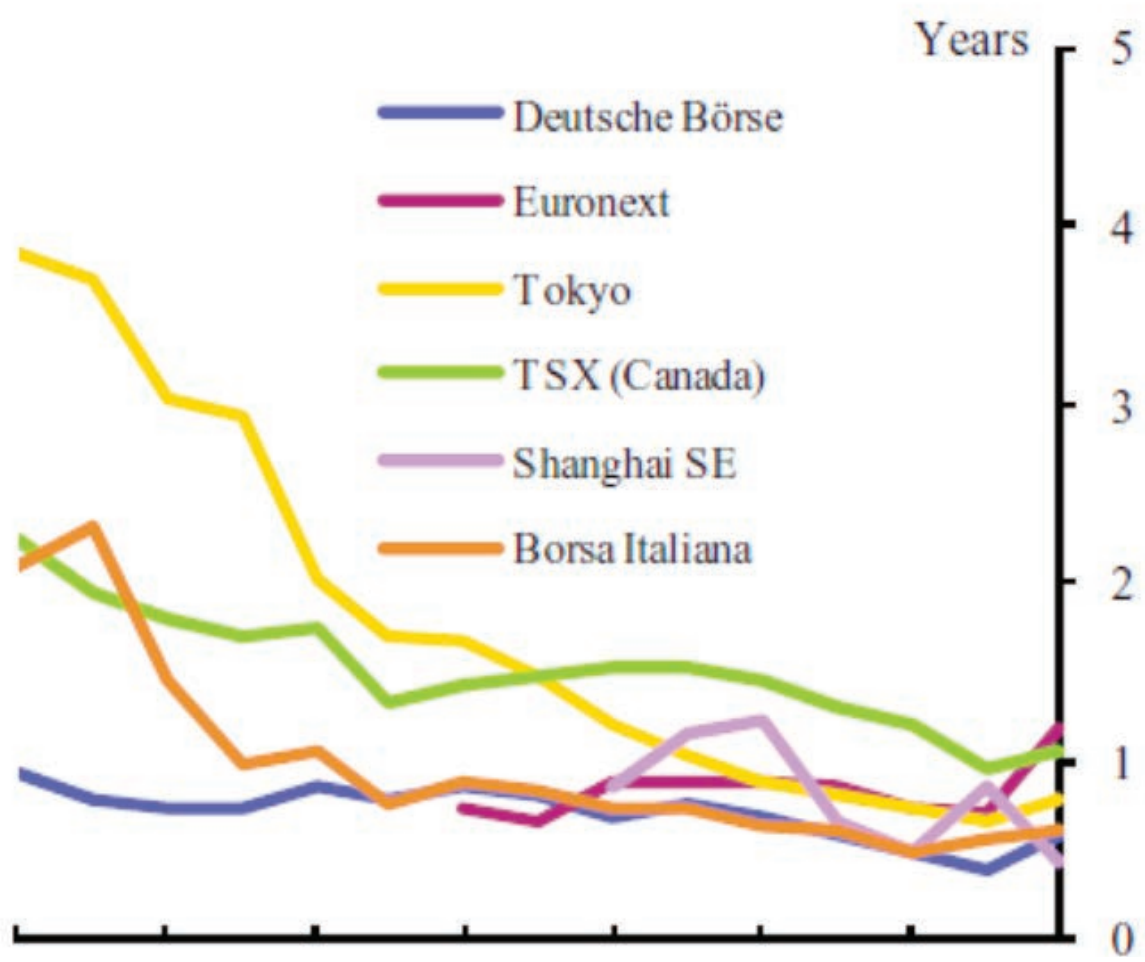

Figure 4. Average holding periods of shares on six stock exchanges. (Source: reproduced from Haldane 2010.) 
Closer to home the widening disparities of income within corporations between executives at the top and employees on the shop floor can be attributed to the changing nature of the corporation. So too can the disparities in wealth between those who own and control corporations and the rest of society and the failure of governments to be able to raise tax from highly profitable transnational corporations. So too can the breakdown in trust in the financial sector where the interests of shareholders and executives have diverged from those of their customers and creditors.

That a single organisational form can perform so many different functions from the one-man enterprise to the corner shop to the conglomerate, from social enterprise to manufacturing to public infrastructure, from the no-tech to the low-tech to the high-tech is truly remarkable. That the corporation can explain the growth of nations around the world and the failure of others to progress is indicative of its macroeconomic significance. That the different nature of the corporation is associated with social benefits and ills and its changes over time with their emergence and eradication suggests that it is to the corporation that we should turn for the source of both our prosperity and our impoverishment.

The fact that the corporation has become footloose and timeless could be a source of tremendous well-being that frees it from the political constraints and historical conventions to which we are currently subject. To the economist the combination of well-functioning competitive and complete markets together with well-governed corporations that pursue the wealth of their shareholders is the source of economic prosperity.

With the emergence of the mindful corporation we could therefore be on the edge of the most remarkable prosperity and creativity in the history of the world. On the other hand, we could equally well be at the mercy of corporations that are the seeds of our destruction through growing inequality, poverty and environmental degradation that give rise to social disorder, national conflicts and environmental collapse on scales that are almost impossible to conceive of today. We are therefore on the border between creation and cataclysm and the corporation is in large part the determinant of which way we will go.

Our future therefore depends on reinventing the corporation for its seventh and final age. But describing what it will take to get us to nirvana rather than into a collapsing supernova, we first need to look backwards to understand where are and how we got here to the cusp of nirvana and supernova. 


\section{PART 2-HOW WE GOT HERE}

The intellectual history of the corporation is one of benign neglect that lagged far behind the emergence of economics from the age of enlightenment. To the extent that the joint-stock corporation was discussed, it was largely to suggest that it should not exist. For Adam Smith, specialisation of labour was a source of economic prosperity, but the corporation was infested with conflicts of interest between management and shareholders to the point that "negligence and profusion, therefore, must always prevail, more or less, in the management of the affairs of such a company.' ${ }^{2}$

It was the market and exchange rather than the corporation that was the source of economic prosperity. Even for Alfred Marshall-the grandfather of industrial economics writing more than a hundred years later - the existence of the corporation rested precariously on the integrity of the English gentleman. 'It is a strong proof of the marvellous growth in recent times of a spirit of honesty and uprightness in commercial matters, that the leading officers of great public companies yield as little as they do to the vast temptations to fraud which lie in their way. ${ }^{3}$

It was not until Ronald Coase writing in the 1930s that the corporation was given a more solid foundation as an alternative lower cost way of organising economic activity than the marketplace. ${ }^{4}$ Once one thinks of the corporation in these terms then it clearly takes on a relevance of its own as a legitimate subject of study and from this sprang the intellectual underpinnings of business school education and scholarship.

But what continued to dominate economic analysis of the corporation was precisely the issue that had concerned Adam Smith and Alfred Marshall-its dependence on managers who at best were negligent and at worst fraudulent. ${ }^{5}$ Since it is the shareholders who bear the cost of their managements' negligence and frauds, it is the shareholders who should have the right to prevent them from engaging in such malpractices. With the risk of failure goes the right to govern the corporation, and shareholders should have ownership rights to elect, remove and reward managementcorporate governance. ${ }^{6}$

The only problem with this elegant solution was whether shareholders would exercise those rights. So long as the shareholder was the founder of the firm, or a family, then the answer was yes. But if the shareholder was one amongst many institutional

\footnotetext{
${ }^{2}$ Smith (1776), Book V, Chapter 1.

${ }^{3}$ Marshall (1892), Book IV, Chapter 12.

${ }^{4}$ Coase (1937).

${ }^{5}$ See, for example, Alchian \& Demsetz (1972) and Jensen \& Meckling (1976).

${ }^{6}$ Friedman (1970) and Hansmann \& Kraakman (2001).
} 
investors as we have today, then the answer is no. Shareholders might have the rights, but they do not have the incentives or knowledge to exercise them. ${ }^{7}$

It is this failure of governance with which all the ills of the corporation today are associated. Two hundred and fifty years after Adam Smith first identified the problem, we are still trying to grapple with it. The joint-stock corporation should not have existed, but not only have we allowed it to but we have encouraged it to become the most important institution in our lives and we are paying the price for it.

So looking through an economic lens, nearly all policy towards the corporation has been concerned with solving this one issue of how to make management more accountable to their shareholders. A recent front cover of The Economist proclaimed 'capitalism's unlikely heroes' to be the hedge fund activists who strike terror into the boards of public corporations by purchasing blocks of shares in companies and then demanding seats on their boards with a view to shaking up and shaking out their negligent if not fraudulent management. ${ }^{8}$ They are the new corporate raiders-the Carl Icahns and the Lord Hansons of the 2010s - the heroes of The Economist's capitalism who will bring us to our state of nirvana.

In fact, the new corporate raiders will bring us no more happiness than their predecessors. There is some irony in the conclusion that markets for corporate control are needed to ensure that activities are undertaken more efficiently in corporations than in product markets. This reductionist conclusion brings the corporation back to its primordial market form and once again we end up bereft of a theory of it.

The reason for this conceptual failure is that the intellectual basis of the corporation from Adam Smith to the present is fundamentally wrong. The defect of the corporation is not its lack of accountability of management to its shareholders or the failure of shareholders to exercise their rights of control. On the contrary, these are the very attributes of the corporation that make it into such a remarkable and valuable institution.

Why? Three reasons: contract and market incompleteness, unenforceability, and infeasibility. Let me unpack this economic and legal jargon. The idea that shareholders bear the risks and rewards of the corporation rests on the notion that everyone else - we as employees, customers and creditors - are protected by contracts that ensure that we are paid, supplied and repaid. Only shareholders do not have contracts that ensure that they are paid a dividend or can claim their money back. Once invested, a shareholding in a firm becomes its permanent capital that cannot be claimed back and only sold to others through, for example, stock markets. So shareholders as a group are exceptionally exposed to the fortunes of the firm.

\footnotetext{
${ }^{7}$ Fama \& Jensen (1983).

${ }^{8}$ The Economist, 7 February 2015.
} 
But that rests on the assumption that we as employees, communities and creditors are protected by contract. As employees in the Cadbury factory in Somerdale discovered when Cadbury was taken over by Kraft in 2010, or employees in the sweatshops in Bangladesh endured when they erupted into infernos, or citizens of Beijing experienced when inhaling pollution on a daily basis, contracts are very restricted. And as nations and taxpayers discovered during the financial crisis, even if contracts exist, they are often not enforceable if the borrowers - the banks in this case - do not have the money to repay them.

Most seriously of all, there are many for whom contracts and markets are simply irrelevant. They are not relevant in much of the developing world and those living in the slums of Kibera. They are not even conceivable for future generations who do not have a voice let alone a contract to protect them from the destruction of what should be their - as much as our - rain forests and environment.

Shareholders are not therefore by any means the only party exposed to the misfortunes of corporations and the more that we strengthen the rights and powers of shareholders, the more we threaten the interests of others. The Somerdale plant was closed by Kraft, the acquirer of Cadbury; Western corporations scouring the earth for lowest cost suppliers sustain the sweatshops of the world; and banks sell inappropriate financial products to make money at the expense of, not for the benefit of, others.

So long as the corporation is viewed as just an instrument of its shareholders then these problems will become worse and bring us to a point of social, political and environmental catastrophe. But the solution is not simply to transfer control to another party - employees, customers or the state. That merely creates other problems. Mutual organisations owned by their employees or customers are unable to raise substantial amounts of capital and therefore operate in low capital industries such as retailing and wholesaling. Publicly owned corporations are bureaucratic, inefficient and distorted by conflicting political influences.

Most seriously of all, control by employees, customers, the state or shareholders comes at the expense of the party which is not represented at all-future generations. Mutual organisations demutualise to allow current generations of customers and employees to benefit at the expense of future generations. Founders of mindful corporations capitalise the future value of the entities that they create through initial public offerings. Hedge funds extract the capital value of corporations they target by seeking higher dividend payouts and repurchases of shares. In other words, the securitisation of corporations has converted them into rent-extraction vehicles for benefiting current at the expense of future generations of owners.

What makes the corporation so remarkable is that it has the power to do the opposite - to be our saviour and source of social as well as economic well-beingprovided that we recognise that our intellectual conception of it is fundamentally 
wrong and that the separation of its control by management from its ownership by shareholders or its control by other parties is its attribute not its deficiency.

How can this be so? The law recognises that the corporation is a legal personality distinct from its shareholders. Its directors owe a fiduciary responsibility to the members of the corporation who are in general its shareholders but in so doing the directors may legitimately uphold the interests of many other parties - its employees, creditors, customers and communities. The directors can and should balance the interests of different parties in pursuit of the prosperity of the corporation. And the owners should ensure that the corporation pursues its long-term not just its immediate prosperity, which may, as the Court of Delaware, the leading jurisdiction over US corporations, has reaffirmed on several occasions, involve forgoing short-term for long-term shareholder returns.

But the delicate balance between the interests of different parties and generations is jeopardised by an excessive focus on shareholder returns or stakeholder interests. While the law permits and even encourages directors to uphold the well-being of others, the market for corporate control and the hedge fund activists make it increasingly difficult for them to do so. That is why nearly every country in the world, with the exception of the UK, protects management through long-term stable shareholders, takeover defences and board structures that impede the replacement of management.

It is through the separation of management and long-term owners from their shareholders that the corporation is able to commit first and foremost to its purpose in delivering the largest social networks, the best Internet search engines, the cheapest washing machines or the most reliable cars. To deliver this purpose it commits to many different parties, including but not exclusively its shareholders, and to future generations as well as to the present. And it is this notion of the corporation as a remarkable instrument of commitment rather than contract or control that has been missing from our conception of the corporation. It is the power to commit to its purpose and to different parties to different degrees in the delivery of that purpose that makes the corporation such a powerful institution.

There is nothing wrong in capitalising future rents to the benefit of current generations, and there may be considerable advantages in so doing to establish strong incentives for wealth creation, provided that this does not come at the expense of, and preferably to the benefit of, future generations of customers, employees, communities and society. As a commitment vehicle, the corporation is exceptionally well placed to achieve that; as an instrument of control it is not.

Why have we failed to recognise this until today? The answer is that the failings of the corporation have not until recently been so manifest. Adam Smith was writing in the second age of the corporation when it was still a public instrument of Parliament. So while he recognised the potential for the corporation to do damage, it was not the central concern of his time. By the time we get to the third age and Alfred Marshall, 
the corporation was owned by families and then individuals who in many cases, such as the Cadburys, Rowntrees, Colmans, Ricketts, Boots and Beechams were people of high integrity and social conscience. It is as we move to the fourth age of the rise of the financial institution, the fifth age of the transnational corporation and the sixth age of the mindful corporation that the power to defraud, destroy and exploit become all too evident.

But while the mind of the corporation is remarkably nimble, the mind of man is not always so. We cling on to intellectual paradigms far beyond their sell-by date. 'All truth passes through three stages: first it is ridiculed, second it is violently opposed and third it is accepted as being self-evident. ${ }^{\prime 9}$ As The Economist article illustrated, we are currently between stages one and two. The problem with accepting the normal rate of progression to stage three is that time is extraordinarily short and by then the damage that will have been done may be irreversible.

So before it is too late, let me then turn to what we need to do to reinvent the corporation for its seventh age - an age of what should be recreation not cremationthe age of the trusted corporation.

\section{PART 3-THE TRUSTED CORPORATION}

The three key determinants of the corporation are purpose, ownership and governance. If the purpose of the corporation is just to make profits, then we are sunk. That is not the purpose of the corporation - it is not what it has been, it is not what it needs to be and it is not what it should be going forward.

The purpose of the corporation is to do things - to make goods and services that benefit us as customers and communities. The corporation should have a real interest in the welfare and well-being of its employees. These products and processes then produce profits. Profits are the product of the purpose of the corporation; they are not its purpose per se.

All the most successful corporations know and do this. But what is much less well understood is how to do it and what it takes for those companies that are not doing it to do it. Some believe that they only have to say it in mission and corporate social responsibility statements and it will happen. That has no plausibility; the tough part is committing to an extent that it becomes irreversible-only then is it credible.

Some of the most successful corporations in the world do exactly that. Examples are Bertelsmann the media company, Bosch the automotive supply company,

${ }^{9}$ This quotation is often attributed to Arthur Schopenhauer, but there is no known citation to it (see Shallit 2005). 
Carlsberg the brewery, and Tata the Indian conglomerate and owner of Jaguar Land Rover. All of these have one thing in common: they are all owned by industrial foundations.

Those industrial foundations devote their profits to investing in their businesses and giving any surplus to charity. But the primary purpose of the industrial foundations is to ensure that the companies below them, such as Bosch and Carlsberg, abide by their purposes, principles and values as laid down by their founders. If they fail to do so, then it is the boards of the foundations that take responsibility for this.

And herein lies the germ of understanding of how one goes from good intention to commitment. What defines these successful and enlightened corporations is a combination of clearly defined purpose, stable and supportive ownership and accountability of boards and directors to the fulfilment of that objective. It is the translation of the entrepreneurship of the founders into a legacy that is of lasting value to humanity. Not only is it then a worthy sentiment, it is a commercial commitment. And, as Figure 5 shows, industrial foundation firms survive much longer than equivalent other firms. While most firms die within 20 years, most foundation firms survive for at least 60 years.

What such enlightened corporations do is to deliver on their stated purpose by balancing and integrating the six different components of capital that constitute business and economic activity-human capital (employees and producers), intellectual capital (our knowledge and understanding), material capital (our buildings and machinery), natural capital (our environment, land and nature), social capital (our public goods and social infrastructure) and financial capital (equity and debt).

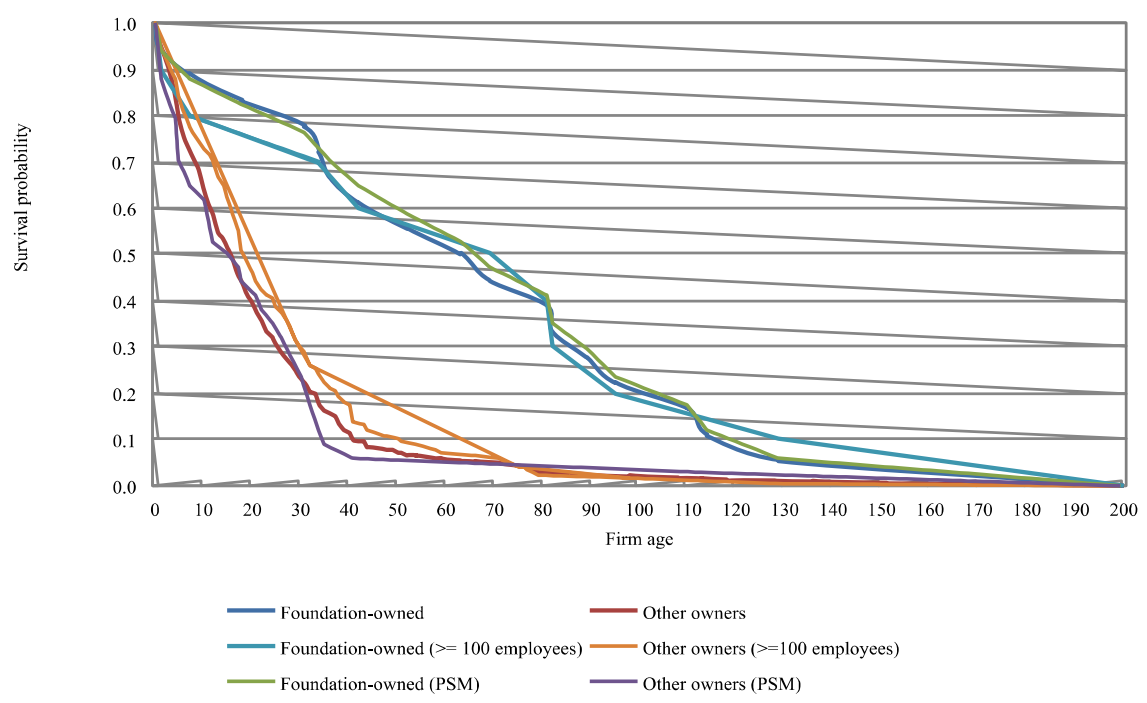

Figure 5. Survival probability of industrial foundation and other firms: Kaplan Meir survival curves. (Source: Børsting, et al. 2016.) 
This balance has changed over time. In its first and second ages, the corporation was a public enterprise producing social capital in the form of canals and railways, in its third age it created material capital in the form of manufacturing industry, in its fourth age human capital in the service firm, in its fifth age increasingly financial capital in the transnational corporation, and intellectual capital in its sixth age.

There is one form of capital that the corporation has not produced at all to date and which, on the contrary, it has consumed voraciously, and that is natural capital. One of the reasons why we stand on the precipice of environmental disaster is its failure to do so. It is not the only failure because in transitioning to financial and intellectual capital we have lost the social capital that originally defined the corporate charter. The preoccupation with financial capital has led to the destruction of social capital on a massive scale.

What is required is for corporations to balance their production and usage of different types of capital. They need to produce balance sheets that account for the human, intellectual, natural and social capital as well as their material and financial capital. They should record their production of these assets and their usage and abusage in their balance sheets. They should report their net worth in relation to all of them and not just their financial and material capital.

To achieve this, company law should be reformed to require corporations to articulate their purposes, to redefine the fiduciary responsibility of the board of directors to be not just to its members but also to the delivery of the stated purpose of the corporation, to produce accounts that measure its performance in so doing and to implement incentive arrangements that reflect the purposes of the corporation. The directors should thereby be accountable both to their members and to those in whose interests the corporation is being run.

This is hardly a revolution - capitalism not only survives but flourishes-but its effect will be profound. It is a private contractual solution to the provision of corporate commitment that does not rely on either public ownership or public law. It has a close parallel in existing corporate law.

One of the most innovative developments of the last 10 years has been the emergence of the public benefit corporation in the US. This has swept across 28 states in the US, most significantly of all Delaware. The public benefit corporation is a company that has a stated public purpose alongside its commercial objectives. These are enshrined in its charter or its articles of association. What gives it teeth is that the board of directors have a fiduciary responsibility to uphold those public purposes and if they fail to do so, then the shareholders can seek injunctive relief to prevent them abusing the corporation's purposes.

Where it is potentially particularly powerful is in relation to the commanding heights of the economy - our banks, utilities, systemically important institutions, 
health service providers and corporations with significant market power. Take, for example, our banks and utilities such as our energy, telecoms, transport and water companies. At the moment we have just one instrument for aligning their interests with those of society and the public they are supposed to serve-regulation. But, as commercial organisations whose primary purpose is to make money for their shareholders, these corporations' interests are diametrically opposed to those of the regulators who act as custodians of the public interest. As a consequence, they do whatever they can to avoid regulation and to turn regulation to a competitive advantage that deters entry of new firms.

That is why regulation has been such a failure. But convert banks and utilities into public benefit corporations and make their licence conditions part of their public purpose, then the fiduciary duty of the directors is no longer to avoid regulation to the benefit of their members but to promote their regulatory requirements as part of their corporate charters.

Of course, not all corporations will be enlightened in the purposes that they adopt and we should impose minimum standards across all firms in terms of bribery, corruption, human rights, market manipulation, market abuse and environmental obligations. We should not tolerate as at present that the social legislation put in place at the beginning of the 19th century to protect workers, through for example the Factory Acts in Britain, should be systematically circumvented by transnational corporations contracting out supply and employing workers in parts of the world that do not have such social legislation. The minimum standards should apply to the payment of living wages and safe and sanitary factory conditions at all stages in the supply chain and production process anywhere in the world.

But we can do much better than that as the founders of the industrial foundations have done. They have not for a variety of reasons simply handed them on to their heirs because they do not have them, do not trust them or do not like them. The reason why this is a defining moment in the life of a company is because, at this point, entrepreneurs have both achieved their commercial vision and accumulated their financial fortune. Their attention turns to their legacy and what the industrial foundation model offers is the potential for perpetuating it in a form where not only the name but the aspiration of the founder is preserved.

The John Lewis Partnership is such an organisation. It is governed by a constitution based on a Settlement in Trust that establishes that the company should be run for the benefit of its employees. But British common law has an aversion to limitations on transfer of property and restricted such arrangements to twenty-one years after the death of someone alive at the time of their creation. In this case, the relevant person was the current monarch Queen Elizabeth II, so her funeral may be followed twenty-one years later by that of another much loved British institution, the John Lewis retail stores. 
What will happen when Sergey Brin and Larry Page in Google and Mark Zuckerberg in Facebook have passed their sell-by date and passed into their solid coffin state? Restricting the talent pool of potential successors to their heirs is a recipe for disaster, whereas, while industrial foundations may involve family members, they are not limited to them.

What this points to is a new form of philanthropy. Currently it can be characterised as accumulate as much wealth as possible, exploiting other parties where necessary and then give it away as an act of penitence in the form of a charity or foundation. That is the history of the robber barons of the past-the Carnegies, Mellons, Rockefellers and Vanderbilts. This has two drawbacks - first, the creation of wealth involves substantial social damage in the process and, second, the wealth that is accumulated is not as productively employed as it might be. Reinvest it instead in productive enlightened corporations and wealth creation is aligned with and assists in wealth disbursement. The social injustice of staggering inequalities of wealth is thereby converted into sources of protection of the most vulnerable through making successful entrepreneurs into enlightened corporate reformers.

But how can we convince the mass of existing unregulated rather than new or regulated firms to adopt more enlightened policies? If the only interest of their owners is in financial gain, then the purpose of these corporations will remain firmly fixed on financial performance. Pension funds, hedge funds and sovereign funds will engage in active long-term sustainable governance only if they believe it to be in the interest of their beneficiaries - their pensioners, investors and citizens - but not otherwise. Enlightened self-interest might encourage a move in this direction as evidence mounts of the superior financial performance of engaged long-term sustainable investment, but we cannot afford to wait on this.

And we do not have to. With foundations offering an alternative form of ownership, customers, employees, communities and nations will be able to determine whether they wish to remain at the mercy of self-interested companies or be protected by those who have a real commitment to them. Foundations convert current divisions created by concentrations of wealth into social advantages by providing the resources required in upholding corporate purpose.

We can make the promotion of such standards not a regulatory minimum but a competitive objective. We can create competition in trust through foundations competing to establish higher standards of trust. They could offer any company the long-term enlightened shareholding that at present eludes so many stock corporations. The Carlsberg foundation is part of the Danish Academy of Sciences. It could use its knowledge and expertise to provide trust services not just to Carlsberg but to any corporation. 
Cementing philanthropy with business brings purpose to the latter and process and professionalism to the former. But the real insight does not derive from philanthropy but from business innovation. The mindful corporations at the start of this paper are examples of successful commercialisation of social capital in the form of social networks. They have devised mechanisms for making the creation of social capital highly profitable.

A striking example of the creation of social capital in a developing country context is the emergence of mobile money in Kenya. Mobile money is the use of mobile phones to provide payment services. Approximately 60 per cent of the Kenyan population uses mobile money products, with the result that the proportion of the population with access to financial services has grown from one-quarter in 2006 to two-thirds in $2013 .{ }^{10}$ Safaricom, the originator of the service in Kenya, found a way to commercialise the low-cost provision of payments services, thereby allowing a substantial proportion of the unbanked of Kenya to become banked.

These are examples of forms of business innovation, not dissimilar to the technological innovations with which we are more familiar. Far from regarding the pursuit of social objectives as a distraction from commercial success, enlightened organisations view social innovation as a source of success. It is the origin of ideas that enhance both commercial and social well-being.

What is required to achieve this is diversity of corporate forms tailored to the particular activities in which companies are engaged. To accommodate diversity, legislation should be enabling rather than prescriptive. It should encourage corporations to adopt legal structures, such as the public benefit corporation in the US or industrial foundation in Denmark. It should avoid regulation that restricts diversity, by, for example, discouraging the listing of dual-class shares on the London Stock Exchange or limiting the duration of settlements in trust in the UK.

\section{PART 4-CONCLUSION}

We have lost trust in the corporation-most acutely in banks but also in the willingness of corporations in general to distribute their earnings fairly between those at the top and bottom of organisations, and with the rest of society through taxation. We have lost trust in corporations not to pursue profits at the expense of destroying our environment, natural habitats and planet.

${ }^{10}$ Muthiora (2015). 
Re-establishing trust in corporations requires a reinvention of the corporation that involves redefining the fiduciary responsibilities of its directors to uphold its stated purpose and to entrust its controlling ownership to those who are responsible for ensuring that the directors satisfy their fiduciary obligations. In so doing, corporations shift from their current self-regarding to an other-regarding state where we can with confidence and credibility trust them.

The importance of this stems from the significance of trust in our lives. Economists regard trust as beneficial in reducing the costs of formal legal contracts. But in a world of extremely incomplete, unenforceable and unfeasible contracts, the significance of trust is much more than that. It is essential to allow us to survive as citizens and communities in a world of intense uncertainty where we rely on others not only to keep to their word but also to have deep empathy and interest in our well-being.

The corporation today is inhumane. It is inhumane because we have taken humans and humanity out of it and replaced them with anonymous markets and shareholders over whom we have no control. Stephen Hawking has warned of the consequence of removing humans from control of science and artificial intelligence in particular, and thereby making us no longer masters of our own minds. We have already done that in the corporation by allowing markets not man to become masters of our mindful corporation.

Underlying this is the fact that we have systematically eradicated the humanities from the study of economics and business. That was not the original foundation of the enlightenment in emphasising rationality over religion. Adam Smith was careful to balance the emphasis he placed on markets in The Wealth of Nations with morality in The Theory of Moral Sentiments. But that balance has been lost in the subsequent 250 years and ethics has been surpassed by efficiency in economics. We need to correct that as a matter of urgency and put humanity and the humanities back into business.

There is, of course, no institution in the world better placed to do that than the British Academy for the humanities and social sciences and I would urge it to adopt this as a programme of debate and research. It is urgent because, without moral corporations, our economic systems will continue to collapse, our financial systems to fail and our environment to degrade. With it we can achieve greater levels of social well-being and economic prosperity than has been possible to date because ultimately a moral corporation is a commercially successful corporation and the competitiveness of nations depends on the moral fibre of its corporations. 


\section{REFERENCES}

Alchian, Armen \& Demsetz, Harold, (1972), 'Production, Information Costs and Economic Organization', American Economic Review, 62: 777-95.

Borsting, Christa, Kuhn, Johan, Poulsen, Thomas \& Thomsen, Steen, (2015), 'Industrial Foundations as Long-term Owners', Center for Corporate Governance, Copenhagen Business School.

Coase, Ronald, (1937), 'The Nature of the Firm', Economica, 4: 386-405. http://dx.doi.org/10.1111/j.1468-0335.1937.tb00002.x

Friedman, Milton, (1970), 'The Social Responsibility of Business is to Increase its Profits', New York Times Magazine 13 September, page SM17.

Goodridge, Peter, Wallis, Gavin \& Haskel, Jonathan, (2014), 'UK Investment in Intangible Assets', Nesta Working Paper 14/02.

Jensen, Michael \& Meckling, William, (1976), 'Theory of the Firm: Managerial Behavior, Agency Costs and Ownership Structure', Journal of Financial Economics, 3: 305-60. http://dx.doi.org/10.1016/0304-405X(76)90026-X

Haldane, Andrew, (2010), 'Patience and Finance', Oxford China Business Forum, Beijing.

Hansmann, Henry \& Kraakman, Reinier, (2001), 'The End of History for Corporate Law', Georgetown Law Journal, 89: 439-68.

Marshall, Alfred, (1892), Elements of Economics of Industry (London: Macmillan).

Muthiora, Brian, (2015), Enabling Mobile Money Services in Kenya: Fostering a Digital Financial Revolution, GSMA Mobile Money for the Unbanked Programme.

Nakamura, Leonard, (2009), 'Intangible Assets and National Income Accounting: Measuring a Scientific Revolution', Working Paper No. 09-11, Federal Reserve Bank of Philadelphia.

Shallit, Jeffrey, (2005), 'Science, Pseudoscience, and the Three Stages of Truth', mimeo, Department of Computer Science, University of Waterloo, https://cs.uwaterloo.ca/ shallit/Papers/stages.pdf

Smith, Adam, (1776), An Inquiry into the Nature and Causes of the Wealth of Nations (London: Strahan and Cadell). http://dx.doi.org/10.1093/oseo/instance.00043218

Note on the author: Colin Mayer is the Peter Moores Professor of Management Studies at the Saïd Business School at the University of Oxford. He is a Professorial Fellow of Wadham College, Oxford and an Honorary Fellow of Oriel College, Oxford and St Anne's College, Oxford. He is a Fellow of the British Academy, the European Corporate Governance Institute, and the Royal Society of Arts. He is a member of the UK Competition Appeal Tribunal and the UK government Natural Capital Committee.

Colin Mayer was the first professor at the Saïd Business School in 1994, the Peter Moores Dean of the Business School between 2006 and 2011, and the first Director of the Oxford Financial Research Centre between 1998 and 2005. He was a Harkness Fellow at Harvard University, a Houblon-Norman Fellow at the Bank of England, the first Leo Goldschmidt Visiting Professor of Corporate Governance at the Solvay Business School, Université de Bruxelles, and has had visiting positions at Columbia, MIT and Stanford universities. 
Colin Mayer was chairman of Oxera Ltd between 1986 and 2010 and was instrumental in building the company into what is now one of the largest independent economics consultancies in Europe. He is a director of Aurora Energy Research Ltd. He has consulted for numerous large corporations and for governments, regulators and international agencies around the world.

To cite the article: Colin Mayer (2016), 'Reinventing the Corporation', Journal of the British Academy, 4: 53-72.

DOI $10.85871 / \mathrm{jba} / 004.053$

This article is licensed under a

Creative Commons Attribution-NonCommercial-NoDerivs 3.0 Unported License.

Journal of the British Academy (ISSN 2052-7217) is published by

The British Academy - the national academy for the humanities and social sciences.

10-11 Carlton House Terrace, London, SW1Y 5AH

www.britishacademy.ac.uk 